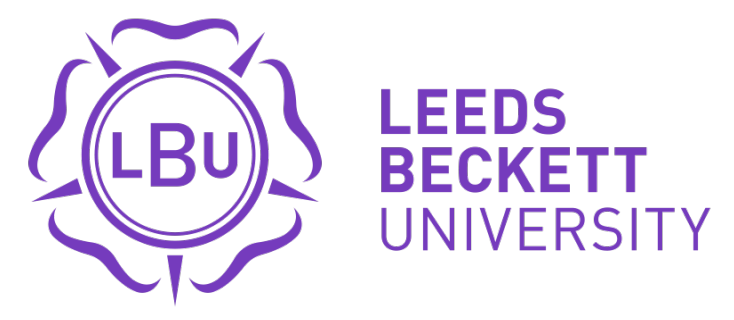

Citation:

Wilson, B and Bekker, HL and Fylan, F (2008) Reporting of Clinical Adverse Events Scale: a measure of doctor and nurse attitudes to adverse event reporting. Quality \& safety in health care, 17 (5). 364 - 367. ISSN 1475-3898 DOI: https://doi.org/10.1136/qshc.2006.021691

Link to Leeds Beckett Repository record:

https://eprints.leedsbeckett.ac.uk/id/eprint/1006/

Document Version:

Article (Accepted Version)

The aim of the Leeds Beckett Repository is to provide open access to our research, as required by funder policies and permitted by publishers and copyright law.

The Leeds Beckett repository holds a wide range of publications, each of which has been checked for copyright and the relevant embargo period has been applied by the Research Services team.

We operate on a standard take-down policy. If you are the author or publisher of an output and you would like it removed from the repository, please contact us and we will investigate on a case-by-case basis.

Each thesis in the repository has been cleared where necessary by the author for third party copyright. If you would like a thesis to be removed from the repository or believe there is an issue with copyright, please contact us on openaccess@leedsbeckett.ac.uk and we will investigate on a case-by-case basis. 
VIGNETTE AND QUESTIONNAIRE.

Health professional's views of clinical adverse event reporting: a

survey.

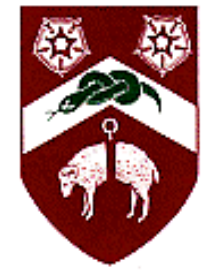

\section{Part 1.}

Please read the following and answer the question. There is no right or wrong answer; it is your view we are interested in. Your response is anonymous and will be treated in confidence.

\section{Vignette:}

Imagine that the following clinical event took place in an average sized acute hospital. Adverse event reporting levels in the hospital are typical of a unit of this size with some events being reported, and others not. Clinical staff believe that if they report adverse events the hospital will not blame them personally for the event.

A patient attends A\&E and it is noted they are allergic to penicillin. Following further assessment, the patient is diagnosed as suffering from pneumonia and is transferred to an inpatient bed. They are treated with penicillin by the clinical team on duty at the time. The patient reacts adversely to the penicillin and suffers an allergic reaction. The clinical team deals with the immediate clinical needs of the patient.

$\begin{array}{llll}\text { Very Unlikely } & \text { Neither likely Likely Very } \\ \text { nor unlikely } & \text { Unlikely } & \text { nor }\end{array}$

If you were part of the clinical team involved in this 0 ------- 1 2 3 $-4$ event, how likely would you be to report it?

(circle one number only)

\section{Part 2.}

The statements listed below have been used by other professionals to describe their views on clinical adverse event reporting. Please read each statement. Circle the number to the right of each statement that best describes your opinion of the statement. A 'clinical adverse event' is any aspect of the healthcare process that may impact negatively on patients, which is not part of the progress of their illness or a result of their own actions. Whether or not to report an adverse event depends on how many people are

$\begin{array}{cccc}\begin{array}{c}\text { Strongly } \\ \text { Agree }\end{array} & \text { Agree } & \text { Disagree } & \begin{array}{c}\text { Strongly } \\ \text { Disagree }\end{array} \\ 1 & 2 & 3 & 4 \\ 1 & 2 & 3 & 4 \\ & & & \\ 1 & 2 & 3 & 4 \\ 1 & 2 & 3 & 4 \\ 1 & 2 & 3 & 4 \\ 1 & 2 & 3 & 4\end{array}$
aware the error has taken place Reporting adverse events protects patients 
The careers of staff who report adverse events suffer

14 Only uncommon adverse events should be reported

15 Writing in a patient's notes that an adverse event has happened is just as good as filling in a separate reporting form

Receiving encouragement from senior clinical staff encourages me to report

1

1 The procedures in this hospital are clear on how to report adverse events am not doing my job properly unless I report adverse events

11 My colleagues expect me to report adverse events

12 Reporting adverse events creates problems for me adverse events

Having an Adverse Event Monitoring Unit based in the hospital encourages staff to report errors

I am not permitted to report adverse events

1

1

You should only report those adverse events where something can be learned from them

Reporting adverse events is a method through which to pinpoint blame Adverse events can't be prevented so there is no point in reporting them

Reporting adverse events lets colleagues gossip about my involvement in the event

1

1
4

4

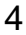

4

4

4

4

4

4

4

4

4

26a. Have you ever witnessed, or been involved in, an adverse event? (tick one box): 26b. If yes, have you ever reported an adverse event? (tick one box):

27. How likely are you to report an adverse event in the future?:

very unlikely $\square \quad$ unlikely $\square \quad$ neither likely/ nor unlikely $\quad \square \quad$ likely $\square \quad$ very likely

28. What is your age?

29. Are you: Male $\square$

Female $\square$

30. When did you first receive a clinical qualification? (if applicable) Date:

31. What is your profession? (e.g. Nurse/Doctor/Midwife)

32. What is your staff grade? (e.g. SHO/D grade) (If applicable)

33. What is your specialty? (If applicable) (e.g. Oncology, Psychiatry)

34. What type of additional qualifications (if any) do you have? (MD, MSc, diploma, etc)

Thank you for taking the time to complete this questionnaire. Please return it in the envelope provided. If you would like to be entered in the draw, please complete the attached slip. Your name will NOT be entered into the study's research database. 